\title{
Nowomowa - stare narzędzie do nowych celów. Jak skutecznie używać nowomowy do deprecjacji „,wroga”?
}

\section{Ewelina Ewa Gwara \\ Uniwersytet Łódzki}

\begin{abstract}
Abstrakt. Celem artykułu jest zbadanie, czy język współczesnych polityków zawiera w sobie elementy nowomowy, a także jaką rolę w nowomowie odgrywają emocje. Punktem wyjścia przeprowadzonej analizy jest typologia cech współczesnej nowomowy stworzona przez M. Głowińskiego, wyodrębniająca takie elementy, jak: dychotomiczne widzenie świata, ideę wroga, spiskową wizję świata. Na podstawie typologii M. Głowińskiego, w artykule dokonano analizy werbalnych, jak i niewerbalnych zachowań trzech polityków: Jarosława Kaczyńskiego, Janusza Palikota oraz nieżyjącego już założyciela partii politycznej Samoobrona, Andrzeja Leppera.
\end{abstract}

Słowa kluczowe: nowomowa, emocje, dyskurs polityczny, inwektywy, socjologia emocji

\section{Wstęp - nowomowa dawniej i dziś}

Termin nowomowa (ang. newspeak) zaczerpnięto z klasycznej już dziś książki Georga Orwella Rok 1984. Oznaczał on formułowanie wypowiedzi i języka w nowy sposób, odmienny od tradycyjnie 
przyjętych reguł. Było to sztuczne i nadmierne skracanie słownictwa. Orwell pisał: „Czy nie rozumiesz, że nadrzędnym celem nowomowy jest zawężenie zakresu myślenia? W końcu doprowadzimy do tego, że myślozbrodnia stanie się fizycznie niemożliwa, gdyż zabraknie słów, żeby ją popełnić. [...] Z roku na rok będzie coraz mniej słów i coraz węższy zakres świadomości” (Orwell 2010: 63). Nowomowa to „język międzynarodowego komunizmu" (Bartmiński 2010: 21). Nowomową, jako językiem polityki, w Polsce zajął się Michał Głowiński (zob. Głowiński 1999; 2009). Wyróżnił on cztery główne wyznaczniki nowomowy (Głowiński 2009: 12-14):

1. Narzucanie wyrazistego znaku wartości;

2. Zmierzanie do „silnego i bezpośredniego oddziaływania” za pomocą pragmatyzmu i rytualności'

3. Magiczność, „słowa nie tyle odnoszą się do rzeczywistości, nie tyle ją opisują, co tworzą";

4. Duże znaczenie „decyzji arbitralnych”;

oraz dwa dodatkowe (Borkowski 2003: 28):

1. Antykomunikacyjność;

2. Idiomatyczność.

Pierwsza z cech, silne wartościowanie, niesie ze sobą dużą dychotomiczność języka. Politycy używający nowomowy stosowali podział na dobrych i złych, swoich i obcych itp. Ocenianie wypowiadanych przez dygnitarzy treści stało się ważniejszą kwestią aniżeli ich analiza znaczeniowa. Pragmatyzm w nowomowie oznacza możliwość dopasowania się języka do odbiorców i okoliczności. Nie oznacza to jednak pełnej elastyczności, gdyż nowomowa cechuje się także rytualnością, toteż język polityki ma swoje ograniczenia, konkretne wytyczne i nie można ich dowolnie przekształcać (weźmy jako przykład język przemówień rocznicowych za czasów PRL). Trzecia z wymienionych cech nowomowy - magiczność, odnosi się do stosowania pewnego 
rodzaju utartych frazesów, komunikatów o charakterze zdań oznajmujących. Politycy w swych przemówieniach wypowiadali się o kwestiach przez nich pożądanych w taki sposób, jakby były one już faktem, chociaż jak wiadomo, bardzo często nigdy nie znajdowały odzwierciedlenia w rzeczywistości. Arbitralność podejmowanych decyzji dotyczy także sposobów używania języka. Władza ludowa mogła w każdej chwili ogłaszać, jak należy się wyrażać, jakim stylem i przy użyciu jakiego słownictwa (Głowiński 2009: 12-14).

Cechy dodatkowe nowomowy, czyli antykomunikacyjność i idiomatyczność jeszcze pełniej uwypuklają jej charakter. Nowomowa w założeniu nie jest stylem przemawiania nastawionym na uzyskanie informacji zwrotnej od odbiorcy, nie jest to styl otwarty na taką informację. Uznawana jest za styl jednokierunkowy - to zawsze tylko politycy zwracają się do społeczeństwa, a nie odwrotnie. Z kolei wspomniana idiomatyczność wskazuje, iż nie można dokonać oceny nowomowy, ponieważ trudno byłoby ją przełożyć na język pierwotny (Borkowski 2003: 28).

Warto wspomnieć, iż nowomowa „polega na kontaminacji językowego tabu i eufemizmu o różnym stopniu nasilenia. Cała nowomowa zbudowana jest na antyfrazie: białe nazywane jest czarnym" (Borkowski 2003: 28).

W nowomowie bardzo ważną funkcję pełnią hiperbole, eufemizmy, metafory, czy niejednoznaczności słów. Należy dodać, iż język nowomowy jest językiem bardzo emocjonalnym. Ma ona również swoje „ulubione” słowa. Szczególnie często $\mathrm{w}$ wystąpieniach politycznych używa się zwrotów: wrogowie, historyczny, słuszny itp. (zob. Głowiński 2009). Partia rządząca poradziła sobie również z cytowanymi tekstami. Co prawda, same cytaty nie były naruszane, to jednak każdy z nich musiał być opatrzony odpowiednim, mocno wartościującym dodatnio lub ujemnie opisem, np. „tak prasa burżuazyjna...” (ibidem: 28). 
Nowomowa jest językiem władzy, a jego cechą jest uzurpacja, co oznacza, iż niektórzy politycy uważają siebie za jedynych godnych ludzi, którzy mogą sprawować władzę nad krajem, przedstawiają jedyną słuszną prawdę (Bartmiński 2010: 22).

Podsumowując, można stwierdzić, iż w tekstach lub przemówieniach konstruowanych zgodnie z zasadami ówczesnej nowomowy, to ideologia komunistyczna przeważała nad sensem przekazywanych treści (Bralczyk 2013: 68).

Czasy, kiedy Polską rządzili komuniści, minęły. Wydawać by się mogło, że wraz z komunizmem zniknęła także towarzysząca mu nowomowa. Jednakowoż, jak twierdzi M. Głowiński, zjawisko to nadal występuje w polskiej polityce, aczkolwiek przybiera trochę inną formę. „Nowomowa przeżyła upadek komunizmu, i nie dziwi mnie, że dziś tym językiem posługuje się prawica antykomunistyczna” (Głowiński 2009: 250). Zmiana, jaka dokonała się w sferze nowomowy, to możliwość publicznego jej krytykowania, co oczywiście było surowo zabronione i karane w PRL. Niektórzy nawet są zdania, iż bez cenzury nowomowa nie istnieje w wersji klasycznej (Kudra, Jeziorska 2010: 187). M. Głowiński zauważa trzy fundamentalne wyznaczniki, które towarzyszą teraźniejszej nowomowie. Są to:

1. Dychotomiczne widzenie świata - tylko „nasze” idee są słuszne, inne partie są „złe”;

2. Idea wroga - kto nie jest $\mathrm{z}$ nami, ten jest przeciwko nam, a więc jest naszym wrogiem;

3. Spiskowe widzenie świata - oprócz tego, że nasi przeciwnicy są naszymi wrogami, to dodatkowo nieustannie spiskują przeciwko nam i zagrażają, są szkodliwi społecznie (Kudra, Jeziorska 2010: 212-213).

Jak twierdzi cytowany już autor: „panowanie władzy nad językiem [...], wyraża się w tym, że przyznaje sobie ona prawo narzucania słowom i formułom dogodnych dla siebie znaczeń" 
(ibidem: 230).W celu uzyskania poparcia wyborców, politycy wykorzystują także szereg technik propagandowych, takich jak: perswazja, manipulacja, sugestia. Przyjęty przez działaczy politycznych styl językowy ma za zadanie wywołać u odbiorców określone emocje. Politycy argumentując w określony sposób indywidualne racje, chcą narzucić wyborcom swoją wolę (Przyłęcki 2012: 8). Generalnie jednak nie da się jednorako określić języka polityki. Współcześnie jest on bardzo zróżnicowany. Cechą niezmienną jest natomiast jego funkcja, czyli dyktowanie wyborcom przez nadawcę własnego świata wartości (Kamińska-Szmaj 2001: 8).

Partią, która najczęściej posługuje się nowomową, jest zdaniem M. Głowińskiego Prawo i Sprawiedliwość: „jestem przekonany, że PiS-owska władza mówi Gomułką" (Głowiński 2009: 249). Wypowiedzi przedstawicieli tej partii cechuje ogromna podejrzliwość, dostrzeganie wszędzie teorii spiskowych, obarczanie winą za wszystko „Układu” (ibidem: 249). Autor pozwala sobie nawet użyć sformułowania "pisomowa” (ibidem: 224). Nowomowę IV RP nazywa się neonowomową, bądź „banalną nowomową" (Kudra, Jeziorska 2010: 188). Język PiS uważa się za nowomowę również $\mathrm{z}$ tego względu, że polaryzuje wizję świata, przeważają w nim elementy wartościujące nad neutralnymi, jak również dokonuje się wartościowania słów, które dawniej były neutralne (Kępa-Figura 2010: 238).

Ponadto, M. Głowiński wskazuje na kolejną cechę języka polityki, czy też nowomowy, a mianowicie retorykę nienawiści, objawiającą się: przedstawianiem bezwzględnych racji (oczywiście swoich); oskarżaniem konkurentów politycznych bez zwracania się do nich; dychotomicznym podziałem „my-oni”; spiskowym widzeniem świata; silnie negatywnym wartościowaniem grup przeciwnych. Ostatnim wyznacznikiem retoryki nienawiści jest apodyktyczny podmiot mówiący, którego racje są oczywiście bezdyskusyjne (Głowiński 2009: 242-246). 


\section{Analiza wystąpień sejmowych - współczesna nowomowa}

Rozpoznanie nowomowy w wystąpieniach dygnitarzy sprawujących władzę w PRL nie byłoby zadaniem trudnym. Ówczesny język polityczny przesiąknięty był sformułowaniami bezsprzecznie kwalifikowanymi jako nowomowa. Współcześnie, choć newspeak w wydaniu polskim nadal funkcjonuje, jak zauważa M. Głowiński, to jednak stosunkowo trudno wskazać typowe zwroty, bezspornie uznawane za nowomowę. Analiza objęła dyskurs publiczny, do którego zgodnie z definicją należy zaliczyć dyskurs parlamentarny, np. transmisje debat parlamentarnych (Czyżewski, Kowalski, Piotrowski 2010: 19). Autorka przeglądając materiały audiowizualne na stronie YouTube, zdecydowała się poddać analizie dziesięć wystąpień polskich polityków: osiem z nich to wystąpienia przedstawiciela Prawa i Sprawiedliwości - Jarosława Kaczyńskiego, jedno jest wypowiedzią Janusza Palikota z Ruchu Palikota (obecnie Twój Ruch), oraz jedno nieżyjącego już założyciela partii politycznej Samoobrona, Andrzeja Leppera.

Do analizy wykorzystano następujące materiały źródłowe:

I) Kaczyński vs Tusk - Daj Pan spokój, 24.01.2014, opublikowany 25.01.2014, liczba wejść na YouTube: 53476 (http://www.youtube.com/watch?v=kLrM-SOfpjk [dostęp 17.06.2014]);

II) Kaczyński: Zamach $w$ Łodzi to efekt kampanii nienawiści, opublikowany 19.10.2010, liczba wejść na YouTube: 5759 (https://www.youtube.com/watch?v=6S4UkCasrOg [dostęp 17.06.2014]);

III) Kaczyński: Gaszono papierosy na szyjach modlacych się kobiet, opublikowany 21.10.2010, liczba wejść na YouTube: 7864 (http://www.youtube.com/watch?v=Kg5EDWB7TC8 [dostęp 17.06.2014]); 
IV) Kaczyński - Jesteście partia oszustów i złodziei, opublikowany 25.01.2014, liczba wejść na YouTube: 59925 (http://www. youtube.com/watch?v=GroeGfOijWI [dostęp 17.06.2014]);

V) J. Kaczyński masakruje Tuska i jego POpleczników, opublikowany 15.04.2012, liczba wejść na YouTube: 49861 (http://www.youtube.com/watch?v=cfU26lyIBxE [dostęp: 17.06.2014]);

VI) Jarosław Kaczyński - wystapienie z 23 stycznia 2014 r., opublikowany 23.01.2014, liczba wejść na YouTube: 13458 (https://www.youtube.com/watch?v=ATDvq8p0Ft0\&list=PLXhNnC497wm_5Jwy8HGGNfVw5OKxlDmvc\&index=5 [dostęp 17.06.2014]);

VII) Jarosław Kaczyński - wystąienie z 22 maja 2013 r., opublikowany 22.05.2013, liczba wejść na YouTube: 2402 (https://www.youtube.com/watch?v=wmYFD-nlouIlouI [dostęp 17.06.2014]);

VIII) Debata nad referendum emerytalnym 30.03.2012 - Jarosław Kaczyński (PiS), opublikowany 30.03.2012, liczba wejść na YouTube: 3395 (https://www.youtube.com/ watch?v=bqVBDx_avdc [dostęp 17.06.2014]);

IX) Palikot do PiS - wasze miejsce jest $w$ więzieniu, opublikowany 09.11.2012, liczba wejść na YouTube: 36551 (http://www. youtube.com/watch?v=G8IMe-OxoT4 [dostęp 17.06.2014]);

X) Andrzej Lepper - Stużby specjalne, politycy $i$ mafia - PEŁNA WERSJA, opublikowany 17.10.2012, liczba wejść na YouTube: 290527 (https://www.youtube.com/ watch?v=A2EFjHIyD-Y [dostęp 17.06.2014]).

Autorka postanowiła przeprowadzić analizę w oparciu o następujące wyznaczniki towarzyszące współczesnej nowomowie:

1. Dychotomiczne widzenie świata,

2. Idea wroga,

3. Spiskowe widzenie świata. 
Ponadto analiza objęła interpretację zwrotów nacechowanych emocjonalnie, które wielokrotnie pojawiały się w przytaczanych wypowiedziach.

Warto dodać, iż emocje „wskazują nam naszą pozycję w świecie i określają relacje wobec innych oraz wobec naszych celów, motywów i interesów" (Lewis, Haviland-Jones 2005: 80). Emocje bardzo często towarzyszą politykom, szczególnie w stosunku do grupy „oni”, tworzą wtedy system wrogości (Lisiecka 2013: 57).

\subsection{Dychotomiczne widzenie świata}

Jak już zostało powiedziane, jedną z cech charakteryzujących współczesną nowomowę jest dychotomiczne widzenie świata. Partia wykorzystująca newspeak w swoich wypowiedziach przedstawia własne działania jako te najlepsze, najbardziej skuteczne, najkorzystniejsze dla społeczeństwa. Natomiast programy czy reformy innych, konkurencyjnych partii ośmiesza, stara się wytknąć im jak najwięcej błędów i uchybień, próbując tym samym obniżyć poparcie i odebrać im wyborców. $\mathrm{W}$ analizowanych wystąpieniach sejmowych pojawiały się tego typu zabiegi.

Jarosław Kaczyński w wystąpieniu pt. Kaczyński vs Tusk - Daj Pan spokój, stara się ośmieszyć i ukazać błędy popełniane przez rząd Platformy Obywatelskiej. Jego celem jest również poinformowanie społeczeństwa, iż PO kpi sobie z obywateli:

Wyście stworzyli system polityki, która jest przez politologów nazywana polityką transakcyjną - to jest nazwa sprzed wielu lat - i wyście ten system doprowadzili, można powiedzieć, do perfekcji. Cała wasza polityka to są kpiny ze społeczeństwa i propaganda dla społeczeństwa, i uleganie różnego rodzaju lobby.

(Wypowiedź dotyczy wniosku o wyrażenie wotum nieufności wobec ministra zdrowia Bartosza Arłukowicza, 24 stycznia 2014) 
Jarosław Kaczyński mówiąc te słowa, chce pokazać, iż partia PO źle rządzi Polską, nie traktuje poważnie obywateli, natomiast partia PiS, zaniepokojona sytuacją, stara się stanąć w obronie Polaków. Wykorzystywanie retoryki dychotomizującej widzenie świata ma na celu zdemaskowanie działalności PO, poprawę własnego wizerunku, a w konsekwencji zyskanie poparcia wyborców. Można domniemywać, iż Jarosław Kaczyński jest przekonany o swojej omnipotencji (Kłosińska 2012: 82-83) - on i jego partia są w stanie poprawić byt wielu Polaków, są podporą dla obywateli. Nigdy nie pozwoliliby sobie na kpiny ze społeczeństwa, gardzą propagandą. Sformułowanie "polityka transakcyjna” jest pojęciem pejoratywnym i nacechowanym negatywnymi emocjami. To właśnie PO stosuje taki rodzaj polityki, pozwala sobie na połączenie zarządzania krajem z prowadzeniem interesów. W swoim wystąpieniu Kaczyński wskazuje, że pojęcie „polityki transakcyjnej” jest znane od wielu lat. Można sądzić, że polityk próbuje nawiązać tu do czasów poprzedniego ustroju i zdemaskować PO jako partię, która czerpie rozwiązania i strategie z komunizmu.

Kolejnym przykładem dychotomicznego widzenia świata jest wystąpienie również Jarosława Kaczyńskiego (film Kaczyński: Gaszono papierosy na szyjach modlacych się kobiet), w którym odwołuje się on do wydarzeń dotyczących krzyża przed Pałacem Prezydenckim. Polityk stwierdził, iż policjanci i funkcjonariusze ABW bezczynnie przyglądali się, jak wandale obrażali ludzi modlących się pod krzyżem, oraz profanowali symbol wiary:

Otóż przypomnę to, co działo się pod krzyżem. Stali tam policjanci, często także funkcjonariusze ABW, a jednocześnie krzyż był profanowany, ludzie byli bici, obrażani, nawet kobiety. Co to w istocie miało znaczyć? Po pierwsze, to znaczy, że w tym kraju nie ma żadnej praworządności, bo policjant ma obowiązek interweniowania w tej sprawie, $w$ takiej sprawie. Jeżeli nie interweniuje, to znaczy, że ma odpowiedni zakaz. Ten, kto zakaz wydał, dopuszcza się przestępstwa, radykalnie tamie zasady praworządności. 
(Odwołanie się do wydarzeń mających miejsce w łódzkim biurze Prawa i Sprawiedliwości i nawiqzanie do zdarzeń przed Pałacem Prezydenckim, 21 października 2010)

Jarosław Kaczyński skomentował zachowanie funkcjonariuszy policji jako niepraworządne, co oczywiście należy uznać za bardzo poważne oskarżenie. W końcu to policja jest jednym z organów stojących na straży praworządności. Ponadto członek PiS zinterpretował postępowanie policjantów jako wykonywanie rozkazów - można domniemywać, iż chodzi o wykonywanie rozkazów Platformy Obywatelskiej. Mamy tu zatem także elementy teorii spiskowej. Przypuszczalnie jednak generalnym celem tej wypowiedzi było ukazanie różnicy, dychotomii pomiędzy partią sprawującą władzę (PO) a PiS; pomiędzy osobami dopuszczającymi się przestępstwa a osobami broniącymi interesów bezbronnych, modlących się ludzi. Konkludując - chodzi o dowartościowanie swojej partii i uzyskanie wzrostu poparcia wyborców, kosztem partii PO. Jarosław Kaczyński, aby wzmocnić swój przekaz, używał takich sformułowań, jak profanacja, bicie, obrażanie. Dzięki tym zabiegom jego komunikat nabrał emocjonalnego (negatywnie nacechowanego) zabarwienia. Polityk nie stronił także od tropów stylistycznych i hiperboli, które są wyznacznikami nowomowy (Głowiński 2009: 22). Nie wystarczyło powiedzieć, że zasady praworządności są łamane - one są łamane radykalnie.

Bardzo wyraźna dychotomia pomiędzy partiami została podkreślona w wystąpieniu sejmowym Jarosława Kaczyńskiego pt. Kaczyński - Jesteście partią oszustów i złodziei, w którym to polityk dosadnie ukazał wyborcom, kim jest partia rządząca:

Otóż tego rodzaju operacje, a nie zaprzeczył Pan, że to radni Platformy Obywatelskiej, właśnie tak się przeprowadza! Każdy to wie! Tylko Panu się wydaje, że Pan to nie wie. Jesteście partią oszustów i złodziei!

(Debata poprzedzająca głosowanie, w którym Sejm nie zgodzit się na odwołanie Bartosza Arłukowicza z funkcji Ministra Zdrowia, 24 stycznia 2014) 
W powyższym cytacie można dokładnie zaobserwować retorykę nienawiści - Platforma Obywatelska została skompromitowana, potępiona. Partia ta, zdaniem PiS, przeprowadza „operacje” mające negatywny wpływ na polskie społeczeństwo. Samo słowo „operacja” posiada ujemny wydźwięk (niesie skojarzenia z wojną albo medyczne). „Zmiana” lub „reforma” nie byłyby tak emocjonalnie odebrane przez słuchaczy. „Operacje” mogą nasuwać skojarzenia z czymś tajnym, skrywanym przed publicznością. Kojarzą się z operacjami wojskowymi bądź tymi przeprowadzanymi wobec opozycji w ustroju komunistycznym. Ponadto, zastosowanie inwektyw „oszuści i złodzieje” zdecydowanie podniosło emocjonalność przekazu. Z pewnością wzbudziło negatywne emocje u osób oskarżanych. W Słowniku polskich wyzwisk, inwektyw i określeń pejoratywnych słowo „oszust” oznacza: „wyłudzacz, kłamca, człowiek ciągnący korzyści z nieuczciwych operacji” (Stomma 2000: 156). Z kolei „złodziej” to „człowiek popełniający kradzieże, czyhający na ludzkie dobro” (ibidem: 225). Cechy te stanowczo kolidują $z$ atrybutami polityka, wobec czego posłowie PO, słysząc powyższe zarzuty, musieli poczuć się dotknięci, obrażeni i zdyskredytowani w oczach społeczeństwa.

W wystąpieniu zatytułowanym Jarosław Kaczyński - wystąpienie z 23 stycznia 2014 r., prezes PiS powiedział wprost o istniejącej dychotomii pomiędzy jego partią a Platformą Obywatelską. Cytat ten znajduje się również w tekście Grzeczność w polityce zawartym w niniejszej publikacji, lecz odnosi do innego wymiaru emocji w polityce, a mianowicie ugrzecznionej formy ironii. W tym przypadku chodzi o zaznaczenie różnic pomiędzy rywalizującymi partiami:

Wysoki Sejmie! Chciałbym przede wszystkim pani poseł Radziszewskiej serdecznie podziękować, naprawdę bardzo serdecznie, bo bardzo jasno zarysowana została tutaj różnica między dwiema partiami, 
różnica zdań. Pani twierdzi, że jest dobrze, w imieniu swojej partii. Ja pozwolę sobie jednak stwierdzić, że jest źle, albo nawet bardzo źle.

(Wystąienie dotyczące wniosku o wyrażenie wotum nieufności wobec Ministra Zdrowia Bartosza Arłukowicza, 23 stycznia 2014)

Partia PiS występuje znowu jako ugrupowanie identyfikujące się z potrzebami zwykłych, biednych obywateli. Ludzie narzekają, nie mają pracy, nie mają odpowiedniego dostępu do usług zdrowotnych, nie są zadowoleni z obecnej sytuacji społeczno-gospodarczej kraju. PO twierdzi jednak, że wszystko jest w jak najlepszym porządku. PiS wobec tego ma tu pole do krytyki i przychyla się do opinii zwykłych obywateli: „jest źle”. Pokazuje zatem: jesteśmy z Wami - to my jesteśmy dobrzy, a Platforma Obywatelska składa się z osób bez empatii, mówiących o sytuacji służby zdrowia jedynie z własnej perspektywy, a nie perspektywy przeciętnych mieszkańców kraju. Jarosław Kaczyński w celu podkreślenia dużych różnic pomiędzy dwiema partiami używa tutaj retoryki ironii. Ta figura stylistyczna służy między innymi do ukazania poczucia własnej wyższości (Łaguna 1984: 25). Kaczyński ironicznie dziękuje poseł Radziszewskiej, stosując także hiperbolę: "podziękować naprawdę bardzo serdecznie”, co zapewne wywołuje jeszcze silniejsze, negatywne emocje u przedstawicieli partii przeciwnej. Polityk w dalszej części wystąpienia mówi:

Ale jest także jeszcze jedna tego przyczyna, która obciąża służbę zdrowia. To jest niewydajność systemu jako całości. System Tuska, o którym tutaj mówiłem, kiedy uzasadniałem wniosek o wotum nieufności dla całego rządu, jest skrajnie wręcz niewydajny, a to przez swoją patologię, z różnych przyczyn kulturowych. W każdym razie jest on bardzo niewydajny i mimo wzrostu PKB w Polsce nie jest w stanie obsłużyć tego skromnego skądinąd zakresu szeroko rozumianych usług społecznych, które był w stanie obsłużyć jeszcze niedawno.

(Sprawa dotyczaca wniosku o wyrażenie wotum nieufności wobec Ministra Zdrowia Bartosza Arłukowicza, 23 stycznia 2014) 
Pojawia się tu bardzo ważne z punktu widzenia analizowanej problematyki nowomowy słowo: system. Można domniemywać, iż słowo system w ujęciu posłów PiS może oznaczać także klikę, sieć powiązań nieformalnych niepoddanych kontroli społecznej. Ponadto, słowo system wiąże się, lub jest synonimem „układu”. „W obecnym języku oficjalnym «układ» jest słowem o wyraźnie sprecyzowanym wskaźniku wartościującym: układ może być - wbrew praktykom zakładanym w języku polskim - jedynie negatywny. Po prostu dobrego układu nie ma! [...] Układ staje się swojego rodzaju workiem, do którego wrzucić można wszystkich tych, których kwalifikuje się jako wrogów” (Głowiński 2009: 227). Zdaniem profesora Zybertowicza „system ma swoich beneficjentów: grupy interesów, najbardziej korzystające z danych rozwiązań instytucjonalnych" (Zybertowicz 2013: 317). Dodatkowo jest to „system Tuska” - wroga i przeciwnika PiS. Wszystkiemu winien jest ów system. Ponadto, system ten zdaniem Jarosława Kaczyńskiego jest niewydajny (hiperbola „skrajnie”) i naznaczony patologią. Polityk twierdzi także, że jeszcze niedawno podstawowe usługi społeczne były zapewniane, a teraz nastąpiło pogorszenie. Można przypuszczać, że sytuacja za czasów rządów PiS była zdecydowanie lepsza - to PO wszystko zaprzepaściło. Wyborcy nie powinni mieć problemów z tym, kogo ponownie wybrać. I w tym przypadku ukazanie dychotomii ma na celu realnie wpłynąć na decyzje obywateli w najbliższych wyborach.

Kolejną porcję krytyki rządu PO można dostrzec w wystąpieniu sejmowym pt. Jarosław Kaczyński - wystąpienie z 22 maja 2013 r. Prezes PiS stanowczo skrytykował sposób zarządzania państwem. Jednocześnie pokazał, że jego partia poczuwa się do służenia społeczeństwu, namawiał do podjęcia współpracy. I znów PiS ma się jawić obywatelom jako partia mogąca iść na ustępstwa, potrafiąca jako pierwsza wyciągnąć dłoń na zgodę: 
Wysoka Izbo, nie wierzymy w ten rząd, nie wierzymy w jego sojuszników ani tych jawnych, ani tych dyskretnych, ale mamy obowiązki wobec społeczeństwa.

(Pierwsze czytanie poselskiego projektu ustawy o Narodowym Programie Zatrudnienia, 22 maja 2013)

Warto w tym miejscu zająć się analizą sformułowania „sojusznik dyskretny". Jest to peryfraza, która opisuje sieć powiązań nieformalnych, klikowe i koteryjne powiązania. Jarosław Kaczyński nie nazywa ich wprost. Wykorzystuje tutaj „immanentną aksjologię języka”, gdzie „dyskretność” oznacza coś ukrytego, podczas gdy w systemie demokratycznym wartością jest otwartość i transparentność działań. Dyskretny sojusznik jest ukryty przed oczami wyborców. Pomaga w niejawny sposób, najprawdopodobniej niezgodny ze społecznymi normami, a być może także z prawem.

W dalszej części wystąpienia Jarosław Kaczyński zaznacza, iż zła sytuacja społeczno-gospodarcza kraju, jak i rosnące niezadowolenie społeczne, są wynikiem nieumiejętnego administrowania przez partię rządzącą. To jej rządy doprowadzają kraj do upadku. Należy się więc jak najszybciej ich „pozbyć”:

Tego rodzaju kryzys mógł do Polski dotrzeć tylko przy fatalnym rządzeniu, skrajnie nieudolnym i obciążonym gigantyczną patologią, m.in. korupcją.

(Pierwsze czytanie poselskiego projektu ustawy o Narodowym Programie Zatrudnienia, 22 maja 2013)

Jarosław Kaczyński, aby podkreślić niekompetentne zarządzanie Polską przez PO, używa w tej wypowiedzi szeregu hiperboli: fatalnie, skrajnie, gigantycznie i za ich pomocą "gra” na emocjach przeciwników politycznych. "Gigantyczna patologia” to jedno ze sformułowań oceniających, tak charakterystycznych dla „nowo- 
mowy”. Cała wypowiedź jest tutaj jednowartościowa. Dobro jest po naszej stronie - po stronie PiS, patologia po stronie rządzących - PO, po stronie zła.

Kolejno w filmie Jarosław Kaczyński - wystąienie z 22 maja 2013 r., członek Prawa i Sprawiedliwości podkreśla następną dychotomię. Z jednej strony jest PiS - jako partia służąca zwykłym ludziom, potrafiąca zrozumieć ich problemy i dylematy, posiadająca umiejętność znalezienia wspólnego języka. Z drugiej strony jest PO - której brakuje odpowiedniego podejścia do obywateli, unikająca z nimi rozmów, bojąca się rozmawiać o dręczących ich problemach:

Powtarzam, stoicie państwo przed wyborem, przed wyborem kolejnej kompromitacji albo też podjęcia drogi, która na pewno jest niełatwa, na pewno jest trudna, ale która może w końcu polskiemu społeczeństwu, temu zwykłemu społeczeństwu - z którym rozmawiamy i nie boimy się rozmawiać, w przeciwieństwie do was - będzie służyła.

(Pierwsze czytanie poselskiego projektu ustawy o Narodowym Programie Zatrudnienia, 22 maja 2013)

Jarosław Kaczyński, aby jeszcze bardziej zdyskredytować PO, zaznacza, iż politykę tej partii czeka kolejna kompromitacja. Dyskredytacja językowa jest formą agresji językowej. Jej celem jest podważenie czyjegoś autorytetu, zmniejszenie zaufania, odebranie wiarygodności jego słów (Zimny, Nowak 2009: 312).

Materiał zatytułowany: Debata nad referendum emerytalnym 30.03.2012 - Jarosław Kaczyński (PiS) dotyczy proponowanego przez szefa PiS referendum na temat wieku emerytalnego. Po raz kolejny pojawia się słowo system i powtórnie ma znaczenie pejoratywne. System ten należy zmienić, gdyż przynosi szkody, jest niesprawiedliwy i krzywdzący jednostki niezamożne. PiS ponownie stoi murem, broniąc interesów zwykłych obywateli - chce im pomóc: 
Otóż to referendum ma także głębszy sens. To jest referendum odnoszące się do tego, czy ten system, gdzie kieszenie jednych są bronione jak niepodległość, a inne nieustannie drenowane, ma być podtrzymywane. My jesteśmy za zmianą tego systemu.

(Debata na temat referendum emerytalnego, 30 marca 2012)

Jarosław Kaczyński, chcąc silnie podkreślić wykorzystywanie finansowe części społeczeństwa, mówi o drenowaniu kieszeni obywateli. Stosuje tu także hiperbolę: nieustannie.

Dychotomiczne postrzeganie świata można również dostrzec $\mathrm{w}$ wypowiedziach przedstawicieli innych partii. W jednym $\mathrm{z}$ wystąpień Janusz Palikot z Ruchu Palikota przedstawił negatywnie, na zasadzie dychotomii, wizerunek Prawa i Sprawiedliwości:

Tak, będziemy o tym rozmawiali w tej chwili, niezależnie od bredni, które wygadujecie, niezależnie od tego, jak niszczycie dobrą opinię o polskim państwie. Nie zniszczycie Polski, nie pozwolimy wam, żebyście tego dokonali.

(Sprawa odnosząca się do informacji Prezesa Rady Ministrów na temat polityki europejskiej, 9 listopada 2012)

PiS oskarżono o niszczenie dobrej opinii o Polsce, mówienie absurdów. Jednocześnie Janusz Palikot dał do zrozumienia, że jego partia ma na względzie troskę o jak najlepszy wizerunek kraju, będzie walczyła, by nikt go nie zniszczył. Zatem i ona próbuje się popularyzować kosztem innej, konkurencyjnej partii. Palikot dwukrotnie używa sformułowania „zniszczycie”. Jest ono silnie nacechowane emocjonalnie. Generalnie cały przekaz ma za zadanie wywołać silne emocje u polityków PiS: niepokój, strach, upokorzenie.

Uosobieniem dychotomicznego przedstawiania swojej partii w stosunku do innych był nieżyjący już prezes Samoobrony Andrzej Lepper. W przeciwieństwie do Jarosława Kaczyńskiego czy Janusza Palikota, którzy odwoływali się do jednej konkuren- 
cyjnej, wrogiej partii, Andrzej Lepper krytykował w mniejszym bądź większym stopniu wszystkie, bez wyjątku. Dodatkowo niekiedy posługiwał się argumentami przypominającymi nowomowę rodem z PRL, przedstawiał sytuacje, które często nigdy nie miały miejsca. Można w powyższym przypadku dostrzec funkcję magiczną nowomowy, a mianowicie nie mówienie o faktach, ale stwarzanie rzeczywistości (Głowiński 1991: 8-9). Poniżej zaprezentowano cytaty $\mathrm{z}$ debaty nad odwołaniem Andrzeja Leppera z funkcji wicemarszałka Sejmu:

Kiedy mówiłem o bezrobociu, które osiągnęło $3 \mathrm{mln}$ oficjalnie, a drugie tyle nieoficjalne, kiedy mówitem, że $80 \%$ tych ludzi nie ma prawa do zasiłku i nie ma środków do życia, oczywiście też nie słuchaliście. Opieka społeczna, może tego nie wiecie, to w końcu sobie zakodujcie w podświadomości, daje ludziom po 20,30, 50 zł miesięcznie na 2, 3, 4 osoby w rodzinie. I co, tego też nie wiecie, tak? Tego też nie słuchaliście, bo po co.

(Sprawa dotyczaca rozpatrzenia wniosku o odwołanie posła Andrzeja Leppera ze stanowiska wicemarszatka Sejmu RP, 29 listopada 2001)

W przytoczonej wypowiedzi, Andrzej Lepper również mocno zarysował stosunek Samoobrony do ludzi biednych, potrzebujących. Obywatele ci mogą zawsze liczyć na wsparcie jego partii. I znowu mamy tworzenie dychotomii: Samoobrona jest partią wspierającą, walczącą o interesy najsłabszych, a pozostałe partie są ugrupowaniami myślącymi jedynie o własnych korzyściach. Jest to prezentacja własnej partii w stylu populistycznym. Przemówienie Leppera na pewno trafiło do osób znajdujących się w gorszej sytuacji materialnej. Polityk bardzo emocjonalnie wypowiadał się, do tego stosując populistyczne hasła. Odwoływanie się do poczucia moralności, sprawiedliwości względem społeczeństwa ma przyczyniać się do osiągnięcia większego poparcia wyborców, a przez to zdobycia wpływu i władzy (Gruszczyński, 
Bralczyk, Majkowska 1999: 79). Z kolei poniższy cytat doskonale oddaje podział na jedną, jedyną partię bliską obywatelom i całą resztę, „żerującą” na ich krzywdzie:

I wy, SLD i PSL, też, oczywiście, w lipcu 1994 r. przyjęliście antyludzką ustawę o eksmisji ludzi na bruk. Wstydziliście się za to, chcieliście ją zmienić; zbyt długo to trwało. Nie myśleliście o tym, że ludzie są biedni w Polsce? Patrzyliście tylko poprzez pryzmat tej sali, gdzie żyje się nieźle? Trzeba spojrzeć tam, na dół. Tam są ludzie, tam są wyborcy, którzy nas tu wprowadzili; jesteśmy tu dzięki nim. Ja tych ludzi tylko broniłem, dlatego że wy sami, przyznając się, iż uchwaliliście ustawę antyludzką, później ją zmieniliście. Ale ile szykan padło pod moim adresem, że broniłem przed eksmisją, że goniłem komornika, do więzienia zamykaliście. Dziękuję wam za to. Broniłem i będę bronił ludzi. Doprowadziliście kraj do ruiny, a naród do nędzy, kulturalnie, bez inwektyw, a teraz o Wersalu marzycie? Na tej sali już go nie będzie, bo kraj tonie, bo ludzie na chleb nie mają i teraz Wersalu chcecie?

(Sprawa dotycząca rozpatrzenia wniosku o odwołanie posła Andrzeja Leppera ze stanowiska wicemarszatka Sejmu RP, 29 listopada 2001)

Widać wyraźnie w powyższej wypowiedzi połączenie krytyki „inteligenckiego etosu” (tzw. Wersal) prezentowanego w zakamuflowanych prawnych działaniach anty-pracowniczych (ustawa antyludzka). „Wersal” jest tutaj peryfrazą dla wyrażenia pewnego sposobu myślenia i działania politycznego, oceniajacego negatywnie. Przymiotnik „antyludzki” dodany do słowa ustawa nadaje działaniom prawnym pewnych partii znaczenie wybitnie negatywne. Połączenie tych dwóch sformułowań w jednej wypowiedzi wzmacnia silnie moc retoryczną krytyki i jej walor emocjonalny. Ponadto, polityk używa takich sformułowań, jak nędza, ruina, dzięki czemu jego komunikat jest bardziej emocjonalny.

Wszystkie z przytoczonych wystąpień w bardziej lub mniej radykalny sposób opisywały dychotomiczny podział na „my” 
i „oni”. Politycy za każdym razem przedstawiali swoją partię jako jedyną sprawiedliwą, której zawsze zależy na dobru wszystkich obywateli, szczególnie tych w najgorszej sytuacji materialnej. Mówcy prezentowali różne argumenty, ale wszystkie z nich miały jeden główny cel - oczernić, znieważyć, ośmieszyć czy zdeklasować przeciwnika, czyli inną konkurencyjną partię, w konsekwencji wywołać emocję gniewu u publiczności. Zabieg ten pozwalał na postawienie własnego ugrupowania w jeszcze lepszej sytuacji. W dalszej części artykułu przedstawione zostaną inne jeszcze elementy współczesnej nowomowy, również mające na celu wpływanie na poprawę własnego wizerunku, przy jednoczesnym niszczeniu wizerunku partii przeciwnej.

\subsection{Idea wroga}

Język „wrogości” jest ciągle niezwykle żywotny w wypowiedziach niektórych polityków (wskazywanie na wroga, poszukiwanie wroga, nazywanie go w sposób wskazujący na wrogość jego działań). Głównym wrogiem każdej partii jest... inna partia, szczególnie ta o wyższej pozycji w sondażach, czy też zyskująca coraz większą popularność. Generalnie tylko zagorzali zwolennicy partii nie są wrogami, zgodnie z zasadą: kto nie jest $\mathrm{z}$ nami, ten jest przeciw nam. „Wrogiem jest każdy inny” (Markowska 2013: 22). A „inny” może być zarówno podmiotem indywidualnym, zbiorowym, jak też instytucjonalnym (Markowska 2013: 22). Wróg pomaga zjednoczyć się partii i obrać wspólny cel. W analizowanych wystąpieniach sejmowych również dostrzeżono tę kategorię.

Bardzo dobrym przykładem wskazania wroga partii jest wystąpienie prezesa PiS pt. Kaczyński: Zamach $w$ Łodzi to efekt kampanii nienawiści. Jarosław Kaczyński całą winą za zamach na polityków swojej partii obarczył Platformę Obywatelską. Ukazał ją w bardzo złym świetle: 
To, co się stało, jest wynikiem wielkiej kampanii nienawiści, która jest prowadzona przeciw Pis od dłuższego czasu. Trudno określić, kiedy był jej początek. Na pewno «moherowe berety» Donalda Tuska to był początek. Później mieliśmy do czynienia z «dorzynaniem watah», z «bydłem» i z całą falą innych ataków.

(Wystąienie na konferencji prasowej zwołanej po ataku na biuro Prawa i Sprawiedliwości w Łodzi, 19 października 2010)

Idea wroga pojawia się w stosunkowo wielu wypowiedziach Jarosława Kaczyńskiego. Można jednak zauważyć, iż zawsze jest nim Platforma Obywatelska. Negatywne rzeczy, jakie dotykają Prawo i Sprawiedliwość, w opinii jej polityków, są winą dygnitarzy PO i ich nienawiści do zwolenników PiS. Prezes PiS przytacza określenia, jakimi miałaby się posługiwać partia PO w stosunku do jego partii: moherowe berety; dorzynanie watahy; bydło. Są to skrajnie pejoratywne określenia, nacechowane silnymi emocjami. Szczególnie słowo dorzynać nie ma prawa kojarzyć się pozytywnie, czy choćby neutralnie, nawet w towarzystwie jakiegokolwiek innego słowa, a na pewno nie w kontekście watahy. Słowo to kojarzy się ze zbrodnią, okrutnym zabójstwem. Ponadto, warto zaznaczyć, iż mamy tutaj do czynienia z postrzeganą animalizacją posłów PiS: bydło, wataha.

W nagraniu zatytułowanym J. Kaczyński masakruje Tuska i jego POpleczników można również usłyszeć wiele zarzutów pod adresem Donalda Tuska, czy prezydenta Bronisława Komorowskiego. Jarosław Kaczyński obwinia ich za katastrofę smoleńską oraz późniejszy podział społeczeństwa w sprawie krzyża przed Pałacem Prezydenckim:

Ponosicie stuprocentową odpowiedzialność za to, że w kilka dni po tym rzeczywistym zjednoczeniu bardzo dużej części narodu, rozpoczęliście kampanię po to, żeby go podzielić, po to, żeby spotwarzyć tych, którzy zginęli, w tym Prezydenta Rzeczypospolitej, rozpoczęliście kampanię, której haniebny charakter nie ma po prostu precedensu w dziejach niepodległego Państwa Polskiego. 
(Sprawa dotyczaca głosowania nad dodaniem do porzadku obrad projektu uchwały przygotowanego przez Prawo i Sprawiedliwość ws. zobowiqzzania rosyjskiego rzq̨du do przekazania Polsce wraku Tu-154M, 13 kwietnia 2012)

Jarosław Kaczyński także w tym przemówieniu stara się jak najmocniej zdyskredytować przeciwników politycznych. Używa określeń mających na celu zwiększenie emocjonalnej siły przekazu. Z pewnością „spotwarzanie” osób, które zginęły w katastrofie smoleńskiej, czy generalnie zniesławianie zmarłych jest nieludzkie, niemoralne. Jarosław Kaczyński wobec tego umiejętnie manipuluje słowami, aby zaszkodzić reputacji PO. Chce wzbudzić negatywne emocje: u posłów $\mathrm{PO}$, aby poczuli się skompromitowani; u społeczeństwa, by straciło zaufanie do PO, poznało partię z gorszej strony, a być może nawet zmieniło preferencje wyborcze. W tym samym przemówieniu, prezes PiS wspomina o Polskiej Liście Hańby, którą można uznać za kwintesencję idei wroga. Ponadto, sama nazwa dość silnie kojarzy się z retoryką stosowaną w czasach komunizmu i z pewnością wpisuje się w specyfikę nowomowy:

[...] to jest hańba, która przejdzie do historii Polski i Pan się zapisze w tej historii razem z tymi, którzy są na Polskiej Liście Hańby.

(Sprawa dotyczqca głosowania nad dodaniem do porzadku obrad projektu uchwały przygotowanego przez Prawo i Sprawiedliwość ws. zobowiqzania rosyjskiego rzqdu do przekazania Polsce wraku Tu-154M, 13 kwietnia 2012)

W powyższym przemówieniu Jarosław Kaczyński zwracał się do ówczesnego premiera Donalda Tuska. Słowo „hańba” wskazuje na emocjonalność całego przedsięwzięcia tzw. „Polskiej Listy Hańby”. Wskazuje się w niej tych, którzy kwestionują ustalenia komisji Macierewicza odnośnie do przyczyn katastrofy smoleńskiej.

W kolejnym przemówieniu, pt. Debata nad referendum emerytalnym 30.03.2012 - Jarosław Kaczyński (PiS), przedstawiciel 
PiS używa sformułowań, jak np. „system postkomunistyczny” czy też „wyeliminowanie nosicieli tegoż systemu”, co także rodzi konotacje z nowomową. Wróg został tutaj bardzo dokładnie opisany. Poprawa sytuacji w państwie polskim może nastąpić tylko po zmianie rządu. Prezes PiS widzi w tej zmianie realną szansę na objęcie władzy. Pojawia się tutaj kategoria system, ale już dzięki przymiotnikowi wiemy, że chodzi o system postkomunistyczny, który ciągle, według mówcy, istnieje:

My nie musimy Wysoka Izbo żyć w dalszym ciągu w systemie postkomunistycznym. W systemie w istocie postkolonialnym. Nie musimy! Możemy ten system odrzucić. Możemy także wyeliminować z życia społecznego jego przedstawicieli, jego nosicieli. Tylko trzeba zmienić władzę.

(Debata na temat referendum emerytalnego, 30 marca 2012)

Idea wroga została także zawarta w wystąpieniu Andrzeja Leppera: Andrzej Lepper - Stużby specjalne, politycy i mafia - PEŁNA WERSJA. Polityk przedstawił PO jako wroga całego społeczeństwa, któremu Samoobrona ma się przeciwstawić i rozliczyć go za wszystkie przewinienia. Warto wspomnieć, iż Andrzej Lepper mówił podniesionym tonem, lekko grożącym, co bardzo przypominało wystąpienia niektórych komunistów:

I oczywiście bohaterowie, Platforma Obywatelska. Tam są mistrzowie w niszczeniu kraju. Nie ma lepszych mistrzów niż ci panowie. [...] Czy myślicie, że będziecie nadal ludzi oszukiwać, że będziecie nadal tak ciągnąć? Panowie, wy się nie boicie tego, że takie słowa mówi Lepper; wy się boicie Leppera i Samoobrony. [...] Znajdziemy ich! Znajdziemy was! Przypomnicie sobie moje stowa z tej trybuny. Znajdziemy was! [...] Postępowanie musi się toczyć.

(Sprawa dotyczaca rozpatrzenia wniosku o odwołanie posła Andrzeja Leppera ze stanowiska wicemarszatka Sejmu RP, 29 listopada 2001) 
Andrzej Lepper, aby ośmieszyć Platformę Obywatelską, ironizuje. Ironia jest zabiegiem retorycznym, niezwykle skutecznym między innymi w kampaniach wyborczych. Zdaniem K. Szymanka, ironią jest „przeciwieństwo między dosłownym a zamierzonym przez autora właściwym sensem wypowiedzi” (Ożóg 2004: 95; zob. także tekst Eweliny Sudry w tej książce). Lepper używając słów bohaterowie, mistrzowie wcale nie uważa posłów PO za wyjątkowe osoby. Uważa, że są mistrzami, ale w niszczeniu kraju. W dalszej części przemówienia polityk wygrażał innym posłom, iż wraz ze swoim klubem parlamentarnym doprowadzi do rozliczenia ich niezgodnych z prawem czynów. Mówiąc to, podnosił głos, mocno gestykulował wskazującym palcem.

Idea wspólnego wroga była znana już od bardzo dawna, jednakże w rozgrywkach między partiami politycznymi nabiera nowego znaczenia. Politycy obrzucają się nawzajem różnymi zarzutami, nierzadko fałszywymi, tylko po to, by publicznie znieważyć lub ośmieszyć przeciwnika i przeciągnąć na swoją stronę jego wyborców. Gra/walka ta staje się coraz bardziej zacięta, a oskarżenia coraz bardziej poważne.

\subsection{Spiskowe widzenie świata}

Ostatnią z wyróżnionych przez M. Głowińskiego cech współczesnej nowomowy jest widzenie świata w kategorii wszechobecnego spisku. W kilku $\mathrm{z}$ analizowanych przemówień wystąpiła ta idea. Prezes PiS (Kaczyński: Zamach $w$ Łodzi to efekt kampanii nienawiści) oskarżył PO o spiskowanie przeciwko niemu i zaplanowanie zamachu na jego osobę:

Mamy tutaj do czynienia z wydarzeniem nowym w polskiej praktyce politycznej i wydarzeniem, które z całą pewnością nie miało charakteru przypadkowego.

(Wystapienie na konferencji prasowej zwołanej po ataku na biuro Prawa i Sprawiedliwości w Łodzi, 19 października 2010) 
Pojawia się w powyższym cytacie trop języka ezopowego, „nie miało charakteru przypadkowego". Możemy się domyślać, że chodzi tutaj o spisek grupy osób, ale dokładnie nie jest powiedziane o kogo chodzi. Język ezopowy nowomowy w nowym systemie demokratycznym pozwala uniknąć bezpośrednich oskarżeń o zniesławienie i wynikających stąd konsekwencji prawnych. Jednak wymowa retoryczna jest tutaj oczywista. To „oni” planowo („nie miało charakteru przypadkowego”) i racjonalnie przygotowali spisek, który poprzez sekwencję określonych wydarzeń doprowadził do tragedii.

W kolejnym wystąpieniu pt. J. Kaczyński masakruje Tuska i jego POpleczników, cytowany już polityk porównał wypowiedź Prezesa Rady Ministrów, używając języka ezopowego, do wypowiedzi komunistów sprzed roku 1989. Stwierdził, iż zapewne ten coś ukrywa i nie mówi całej prawdy:

Przed chwilą wysłuchaliśmy wystąpienia Prezesa Rady Ministrów, które muszę się przyznać przypominało mi wystąpienia z bardzo niedobrych czasów. Z czasów, w których naprawdę można było, że tak powiem kontrfaktyczność posunąć do najbardziej radykalnej wersji, najbardziej radykalnej formy.

(Sprawa dotyczaca głosowania nad dodaniem do porzadku obrad projektu uchwały przygotowanego przez Prawo i Sprawiedliwość ws. zobowiqzzania rosyjskiego rządu do przekazania Polsce wraku Tu-154M, 13 kwietnia 2012)

W powyższym cytacie Jarosław Kaczyński bardzo dobitnie porównuje przemówienie Donalda Tuska do wystąpień komunistów. Poprzedni ustrój polityczny nazywa „bardzo niedobrymi czasami”. Polityk także używając neologizmu, wypowiada się o zakłamaniu tamtego systemu. Nie mówi o podawaniu nieprawdy obywatelom, ale o „kontrfaktyczności”. Ponadto, w tym samym wystąpieniu, Jarosław Kaczyński posądza Donalda Tuska o zaplanowanie spisku i obarcza go winą za katastrofę w Smoleńsku: 
Tak to jest Panie premierze, Pańska wina. To wszystko, co wydarzyło się przed katastrofą, ta wojna, to rozdzielenie wizyt z Pańskiej winy, nie byłoby katastrofy, gdyby nie było tego rozdzielenia. To jest wynik waszej polityki. Niezależnie od tego, co Pan będzie tutaj mówił, w sensie politycznym ponosicie stuprocentową odpowiedzialność za tą katastrofę.

(Sprawa dotyczaca głosowania nad dodaniem do porzadku obrad projektu uchwały przygotowanego przez Prawo i Sprawiedliwość ws. zobowiq̨zania rosyjskiego rzq̨du do przekazania Polsce wraku Tu-154M, 13 kwietnia 2012)

Kolejną teorię spiskową prezentuje prezes $\mathrm{PiS}$ w wystąpieniu Jarosław Kaczyński - wystąpienie z 23 stycznia 2014 r. Jego zdaniem, pewne grupy, a ma tutaj na myśli PO, są żądne środków publicznych, więc próbują również poprzez spisek pozyskać pieniądze ze służby zdrowia:

Otóż mamy dzisiaj w Polsce takie zjawisko, że grupy społeczne, mówię tutaj o grupach niewielkich, ale bardzo wpływowych, mających możliwości, skupionych wokół rządzącej partii, poszukują, można powiedzieć, odczuwają wilczy głód środków publicznych. A ponieważ tych środków publicznych nie ma już tak bardzo dużo, własności publicznej nie ma tak dużo, bo mieliśmy już procesy trwające dwadzieścia kilka lat, służba zdrowia jest tutaj znakomitym polem do działania, znakomitym polem do uwłaszczania się.

(Wystapienie dotyczace wniosku o wyrażenie wotum nieufności wobec Ministra Zdrowia Bartosza Arłukowicza, 23 stycznia 2014)

Teoria spiskowa ujawnia się w sformułowaniach „wpływowe grupy", które mają kontakty z rządzącą partią i próbują dokonać przedsięwzięć niekorzystnych dla Polski. Ponadto odczuwają one „wilczy głód” - nic nie jest w stanie ich powstrzymać. Jarosław Kaczyński użył tutaj przekształconego związku frazeologicznego „wilczy apetyt”.

Ostatnim przykładem teorii spiskowej jest wypowiedź pt. Debata nad referendum emerytalnym 30.03.2012 - Jarosław Kaczyń- 
ski (PiS), w której to osoby „spod ciemnej gwiazdy” są uprzywilejowane, a pozostałe nie odnoszą takich korzyści. Ponadto używa się tutaj przymiotnika, by dookreślić, czym jest system w tym kontekście ${ }^{1}$; rządy PO wprowadziły „antynarodowy system”, w pełni świadome jego konsekwencji:

Jest to system skrajnie nieefektywny pod każdym względem. To jest skrajnie nieefektywny, zabijający wręcz naród system społeczny. To jest system po prostu antynarodowy. To jest system, który przynosi korzyści wąskiej grupie, zresztą spod ciemnej gwiazdy. Wy tego systemu bronicie, to jest główne zadanie Waszej partii. Ale my jesteśmy przeciw.

(Debata na temat referendum emerytalnego, 30 marca 2012)

Po raz kolejny w wystąpieniu Jarosława Kaczyńskiego pojawia się słowo system. Tym razem towarzyszą mu takie przymiotniki, jak: nieefektywny, zabijający, antynarodowy. Słowa te są nacechowane ujemnie. Niosą ze sobą negatywne skojarzenia, w związku z czym wywołują negatywne emocje. Słowo system, czyli układ, uznawane jest za jedno z antysłów IV RP (Bartmiński 2010: 23). Dodatkowo, w wypowiedzi występuje odniesienie do „wąskiej grupy osób”, które są „spod ciemnej gwiazdy”. Grupa ta może przywodzić na myśl koterię, klikę. Jej działania są owiane tajemnicą. Jarosław Kaczyński także w tej wypowiedzi użył niekompletnego związku frazeologicznego „spod ciemnej gwiazdy”. Kompletny związek brzmi „typ/łotr spod ciemnej gwiazdy”. Można zatem domyślić się, jak bardzo negatywnie polityk ocenia osoby współpracujące z PO, a tym samym chce zdyskredytować przeciwną partię, ukazując wyborcom, z kim kooperuje partia Donalda Tuska.

1 Podobnie jak w nowomowie opisywanej przez M. Głowińskiego, mamy różne określenia/przymiotniki dla demokracji: demokracja ludowa, demokracja socjalistyczna itp., tutaj stosuje się ten sam zabieg, by wartościować kategorię „system”: system antynarodowy, system transakcyjny, system Tuska, system naznaczony patologią, system postkolonialny. 
Teorie spiskowe, podobnie jak idea wspólnego wroga, są narzędziami niesłychanie pomocnymi w budowaniu silnej, zjednoczonej wspólnoty politycznej. Partie mocno populistyczne, wykorzystując te teorie w orędziach do swoich wyborców, mogą zapewnić sobie ich niegasnące poparcie, a nawet zdobyć nowych zwolenników.

\section{Opis zachowań niewerbalnych}

Analiza wystąpień sejmowych objęła również zachowania niewerbalne polityków. Podstawą analizy materiałów wizualnych, w tym przypadku nagrań wideo, jest wizualna teoria ugruntowana (visual grounded theory) (zob. Konecki 2012: 12-45). Należy podkreślić, iż materiały wizualne mogą stanowić pełnowartościowe dane empiryczne - jako materiał podstawowy lub uzupełniający (Konecki 2008: 90), gdyż jak się coraz częściej zauważa, współczesna kultura jest kulturą wizualną, kulturą obrazów (Sztompka 2005: 12). Obserwacja gestów niewerbalnych pozwala wnioskować o emocjach odczuwanych w trakcie interakcji (Retzinger, Scheff 2000). Nowomowa z pewnością jest narzędziem, przy pomocy którego dąży się do wzbudzenia u odbiorcy (głównie innych polityków, ale także wyborców) pożądanych emocji. Nierzadko jednak osoba, która stara się wywołać u przeciwnika politycznego negatywne uczucia, sama wpada w pułapkę emocji, nie potrafiąc nad nimi zapanować. Można domniemywać, iż politycy dokładają wszelkich starań, aby zachować kamienną twarz, nie dać się wyprowadzić z równowagi, lecz utrata kontroli nad emocjami zdarza się nawet bardzo doświadczonym graczom sceny politycznej. Analizie poddano zachowania niewerbalne trzech cytowanych w tekście polityków: Jarosława Kaczyńskiego, Janusza Palikota oraz Andrzeja Leppera. W zasadzie każdy z nich reprezentuje inny typ osobowości i posiada odmienne umiejęt- 
ności zapanowania nad własnymi emocjami lub świadomej kontroli ich uzewnętrzniania. Jarosław Kaczyński podczas wielu analizowanych w niniejszym artykule przemówień wygląda na osobę z natury zdystansowaną, niewzruszoną, która umiejętnie, w wyuczony sposób potrafi zapanować nad własnymi emocjami. Bardzo często przybiera mocno wyprostowaną postawę ciała; odpowiednio i starannie układa ręce na pulpicie mównicy i w trakcie przemówienia bardzo rzadko gestykuluje nimi, ewentualnie opuszcza je luźno wzdłuż ciała; patrzy wprost przed siebie, niekiedy zerkając na mównicę, sporadycznie spogląda na odbiorców swojego komunikatu. Jego głos jest spokojny, opanowany, jednostajny. Można by rzec, iż polityk ten świetnie wyuczył się, jak kontrolować własne ciało podczas wystąpień. Okazuje się jednak, że tego typu postawa zazwyczaj towarzyszy mu w wystąpieniach, które sam inicjuje. Odmiennie zachowuje się, gdy inni odwołują się do jego osoby, niejako wyzywają go na pojedynek słowny, krytykują jego poglądy. Wtedy, jak np. w wystąpieniu pt. Kaczyński vs Tusk - Daj Pan spokój, w jego zachowaniu zauważalnych jest szereg detali zdradzających emocje. W takich przypadkach Jarosław Kaczyński zaczyna gestykulować rękoma, niemal przez cały czas wystąpienia jego sylwetka zwrócona jest w stronę krytykujących, ton głosu przybiera ostrzejszą barwę, głos podlega modulacji, przestaje być monotonny. Można także zauważyć, iż „zarządza” wtedy większą przestrzenią, wykorzystuje przestrzeń do gestykulowania, wskazywania na innych polityków, a nawet nieznacznego poruszania się przy mównicy. Z pewnością można założyć, że czuje się dotknięty zarzutami przeciwników, lecz jego postawa nie wyraża gniewu. Usiłuje ukryć swoje wzburzenie i podenerwowanie pod maską pozytywnych emocji - żartuje, ironizuje, uśmiecha się, próbuje odbić piłeczkę, tak aby to rywal poczuł się dotknięty. W niektórych wystąpieniach Jarosław Kaczyński bardzo często opuszcza głowę, czy też patrzy w dół na mównicę. Może to oznaczać podejmowanie prób przypomnienia sobie cze- 
goś, ale też wskazywać na usiłowanie ukrycia emocji (Goffman 1976: 63), szczególnie świadczą o tym wizualne markery, takie jak odwracanie wzroku i spuszczanie oczu w dół (Retzinger, Scheff, 2000: 84).

Janusz Palikot reprezentuje inny typ polityka. W nagraniu zatytułowanym Palikot do PiS - wasze miejsce jest $w$ więzieniu można dostrzec, jakie emocje towarzyszą mu po wysłuchaniu przedmówcy. Palikot mówi bardzo stanowczo, głośno, szybko. Widać u niego wzburzenie, silne zdenerwowanie. Nie kryje swoich emocji - wydawać by się mogło, że robi to świadomie. Często gestykuluje, wymachuje na początku palcem, a potem całą dłonią na polityków Prawa i Sprawiedliwości, jego sylwetka jest skierowana w stronę polityków PiS. Palikot nierzadko używa mocnych słów, które dodatkowo silnie akcentuje. Warto zaznaczyć, że mimo zdenerwowania po wysłuchaniu poprzedniego wystąpienia, polityk ten nie czuje się zagubiony czy zdezorientowany. Pozwala wydobyć się własnym emocjom, ale nie przeszkadza mu to w zachowaniu dużej pewności siebie. Janusz Palikot wykorzystuje emocje do zdeprecjonowania polityków PiS.

Andrzej Lepper z kolei wydaje się najsilniej spośród całej trójki polityków podlegać emocjom. Używa nowomowy oraz wielu populistycznych haseł, aby ośmieszyć, znieważyć, skompromitować inne partie, lecz sposób, w jaki to mówi, jest niezbyt przekonujący. Jego przemówienie jest odpowiedzią na wniosek o odwołanie go ze stanowiska wicemarszałka Sejmu RP, tak więc polityk startuje $\mathrm{w}$ debacie $\mathrm{z}$ niższej, gorszej pozycji. W jego głosie słychać zdenerwowanie, stres. Dość często przejęzycza się, traci wątek, robi pauzy. W drżących dłoniach trzyma notatki. Jego głos także drży, momentami słychać chrypkę, która również może oznaczać stres. Pod przykrywką donośnego głosu oraz szeregu środków językowych (ironii, pytań retorycznych, dowcipów) stara się ukryć swoje zaniepokojenie, lęk, ale nie jest w stanie zapanować nad negatywnymi emocjami. W tym miejscu warto przywołać kon- 
cepcję E. Goffmana, według której zakłopotanie przejawia się między innymi jąkaniem, drżeniem głosu, drżeniem dłoni, czy też przejęzyczeniami (Goffman 2006: 97). Z pewnością można stwierdzić, że Andrzej Lepper jest zakłopotany i pomimo wysiłków, jakie czyni, nie potrafi całkiem ukryć swego skrępowania, co stawia go w jeszcze trudniejszej sytuacji. Przy analizie jego postawy można odwołać się do teorii Thomasa Scheffa oraz Suzanne Retzinger dotyczącej rozpoznawania emocji, a szczególnie markerów wstydu (zob. Retzinger, Scheff 2000: 83). Spośród opisanych przez autorów wskaźników/markerów emocji, w zachowaniu Andrzeja Leppera można dostrzec występowanie paralingwistycznych markerów wstydu (ibidem). W całym przemówieniu polityka częste są pauzy w mówieniu, momenty ciszy, niekiedy jąkanie się, czy brak spójności wypowiedzi.

\section{Podsumowanie}

W niniejszym opracowaniu dokonano analizy dziesięciu fragmentów transmisji z obrad Sejmu, których bohaterami było trzech polityków: Jarosław Kaczyński, Janusz Palikot oraz Andrzej Lepper. Materiał został zbadany w kontekście występowania trzech cech współczesnej nowomowy: dychotomicznego widzenia świata, idei wroga i spiskowego widzenia świata.

Analiza wykazała, iż w przytoczonych wypowiedziach najczęściej pojawiającą się cechą neonowomowy było dychotomiczne widzenie świata. Politycy niemal w każdym wystąpieniu wskazywali na swoją odrębność od przeciwników politycznych, zaznaczając przy tym, iż są od nich lepsi: bardziej moralni, empatyczni, pomocni, mają lepsze sposoby na zarządzanie krajem. Dychotomiczne widzenie świata sprowadza się do podziału: My - Oni, Swoi - Obcy. Politycy, aby zdeprecjonować wroga, stosują retorykę nienawiści. 
Kolejną kategorią w analizie wystąpień polityków była idea wroga. Jak już wcześniej powiedziano, politycy zakładają, że wrogiem partii jest każda inna partia. Dla PiS i Jarosława Kaczyńskiego wrogiem są oczywiście posłowie z Platformy Obywatelskiej, którzy dzielą społeczeństwo, odpowiadają za katastrofę smoleńską oraz prowadzą nielegalne interesy. Andrzej Lepper zaś za wrogów uznał wszystkie ówcześnie rządzące partie. Jego zdaniem, nie potrafią one walczyć o interesy zwykłych ludzi, prowadzą kraj do upadku. Idea wroga jest kategorią bardzo przydatną dla polityków. Pozwala lepiej zintegrować się członkom partii, obrać wspólny cel.

Trzecią i ostatnią z omawianych kategorii było spiskowe widzenia świata. Najlepszym przykładem stosowania tego zabiegu są wypowiedzi Jarosława Kaczyńskiego, który bardzo często przywoływał teorie spiskowe. Podawał, iż jego przeciwnicy - PO, współpracują z „osobami spod ciemnej gwiazdy”, prowadzą nielegalne interesy, starają się osłabić Polskę. Ponadto odpowiadają za katastrofę smoleńską. Spiskowe widzenie świata oraz idea wroga doskonale oddają retorykę nowomowy.

Warto także dodać, iż język cytowanych w artykule polityków był nacechowany emocjonalnie, głównie negatywnymi emocjami. Wykorzystując różne figury retoryczne oraz stosując określone zabiegi stylistyczne, starali się manipulować przekazem w ten sposób, aby zdyskredytować wroga, wzbudzić u niego złość czy zawstydzenie. Bardzo często posługiwali się w tym celu hiperbolami, inwektywami, czy też słowami o silnie negatywnym przekazie, jak np. dorzynać, antyludzka, gigantyczna patologia.

Równie ciekawa okazała się analiza wizualna zachowań polityków podczas wygłaszania przez nich przemówień. Istnieje silne powiązanie między przeżywanymi emocjami a zachowaniami niewerbalnymi.

Jak zaobserwowano, każdy z trzech polityków w inny sposób zarządzał emocjami. Jarosław Kaczyński starał się okazywać je w jak najmniejszym stopniu. W przemówieniach, które sam inicjował, 
w zasadzie nie ujawniał swoich uczuć. Janusz Palikot z kolei zachowywał się przeciwnie, $\mathrm{w}$ analizowanym nagraniu mówił bardzo emocjonalnie, nie krył się ze swoimi odczuciami, przy tym można domniemywać, że było to celowe. Chciał w ten sposób pokazać swoją przewagę moralną nad partią PiS. W najmniejszym stopniu nad swoimi emocjami panował Andrzej Lepper. Wielokrotnie dało się zauważyć, iż wymykały mu się one spod kontroli: robił pauzy w wypowiedzi, gubił wątek, drżał mu głos i dłonie. Emocjonalny styl wypowiedzi Palikota różnił się jednak zasadniczo od emocji obecnych w wypowiedzi Leppera. Pierwszy z nich był pewny siebie, a poprzez emocje świadomie okazywał swoje wzburzenie i złość. Drugi z polityków czuł się niepewnie, niezdecydowanie. Utrata kontroli nad własnymi emocjami nie pozwoliła mu na wzbudzenie emocji u przeciwników politycznych - jego słowa wywoływały jedynie śmiech, co jeszcze bardziej go znieważało/ośmieszało.

Reasumując, należy stwierdzić, że w języku politycznym nadal występują elementy nowomowy. Wydaje się to zadziwiające, gdyż biorąc pod uwagę doświadczenia historyczne i ich krytyczną ocenę, a także samo zjawisko, zresztą również mocno krytykowane, nowomowa powinna zaniknąć wraz z przemianami roku 1989. Tak się jednak nie stało. Politycy, zdaniem H. Kurkowskiej, potrafią dopasować siebie i swój język do realiów. Pojawiające się hasła wyborcze i zwroty są na nowo uaktualniane i ewoluują wraz z linią polityczną (Banasik 2002: 18). Współcześnie język polityczny wielu partii cechuje nowomowa i w pewnym stopniu przypomina ona retorykę stosowaną w czasach PRL. W wypowiedziach posłów widać wyraźnie dążenia do znajdowania wspólnego wroga, czy nadmierne uwypuklanie dychotomii, powiązane $\mathrm{z}$ postawieniem siebie i własnej partii w najlepszym świetle. Jak pisze M. Głowiński: „W konsekwencji język, jakim się władza posługuje, musi być językiem walki, czyli - inaczej mówiąc - językiem spotęgowanej agresji” (Głowiński 2009: 213), z czym zdecydowanie często mamy do czynienia w Sejmie. 


\title{
NEWSPEAK - THE OLD TOOL FOR NEW PURPOSES HOW TO USE NEWSPEAK EFFECTIVELY IN ORDER TO DEPRECIATE THE "ENEMY"?
}

\begin{abstract}
The article aims to examine whether the language of contemporary politicians includes elements of newspeak, as well as what role the emotions play in the newspeak. The starting point of the analysis is a typology of characteristics of contemporary Newspeak created by M. Głowiński, that contains such a elements as: dichotomous view of the world, the idea of the enemy, conspiracy vision of the world. On the basis of typology by M. Głowiński, the article analyzes verbal and non-verbal behavior of three politicians: Jaroslaw Kaczynski, Janusz Palikot, and deceased founder of the political party Samoobrona (Self-defence), Andrzej Lepper.
\end{abstract}

Key words: newspeak, emotions, political discourse, invectives, sociology of emotions

\section{Bibliografia}

Banasik, Aneta (2002), Jak uwodzą politycy? Język marketingu politycznego w kampanii wyborczej '97, Wydawnictwo Uniwersytetu Śląskiego, Katowice

Bartmiński, Jerzy (2010), Język IV RP, czyli o karierze przecieku. Problem wiarygodności dyskursu publicznego, [w:] Maciej Czerwiński, Paweł Nowak, Renata Przybylska (red.), Język IV Rzeczypospolitej, Wydawnictwo Uniwersytetu Marii Curie-Skłodowskiej, Lublin

Borkowski Igor (2003), Świt wolnego słowa. Język propagandy politycznej 1981-1995, Wydawnictwo Uniwersytetu Wrocławskiego, Wrocław
Bralczyk, Jerzy (2013), o języku polskiej polityki lat osiemdziesiatych $i$ dziewięćdziesiątych, Wydawnictwo Trio, Warszawa

Czyżewski, Marek, Sergiusz Kowalski, Andrzej Piotrowski (red.) (2010), Rytualny chaos. Studium dyskursu publicznego, Wydawnictwa Akademickie i Profesjonalne, Warszawa

Głowiński, Michat (1991), Nowomowa po polsku, Wydawnictwo PWN, Warszawa

Głowiński, Michał (1999), Końcówka, Wydawnictwo Literackie, Warszawa

Głowiński, Michał (2009), Nowomowa i ciagi dalsze. Szkice dawne i nowe, Universitas, Kraków 


\section{Nowomowa - stare narzędzie do nowych celów...}

Goffman, Erving (1976), Gender Advertisements, MacMillan, London

Goffman, Erving (2006), Rytuat interakcyjny, przet. A. Szulżycka, PWN, Warszawa

Gruszczyński, Włodzimierz, Jerzy Bralczyk, Grażyna Majkowska (1999), Polszczyzna w komunikowaniu publicznym, Oficyna Wydawnicza Aspra, Warszawa

Kamińska-Szmaj, Irena (2001), Stowa na wolności, Wydawnictwo EUROPA, Wroctaw

Kępa-Figura, Danuta (2010), OBCY pilnie poszukiwany, czyli „obcy” w języku polityków PiS - magia czy rzeczywistość?, [w:] Maciej Czerwiński, Paweł Nowak, Renata Przybylska (red.), Język IV Rzeczypospolitej, Wydawnictwo Uniwersytetu Marii Curie-Skłodowskiej, Lublin

Kłosińska, Katarzyna (2012), Etyczny i pragmatyczny. Polskie dyskursy polityczne po 1989 roku, Narodowe Centrum Kultury, Warszawa

Konecki, Krzysztof Tomasz (2008), Wizualna teoria ugruntowana. Rodziny kodowania wykorzystywane $w$ analizie wizualnej, „Przegląd Socjologii Jakościowej", t. 4, nr 3, s. 89-115

Konecki, Krzysztof Tomasz (2012), Wizualna teoria ugruntowana. Podstawowe zasady i procedury, „Przegląd Socjologii Jakościowej”, t. 8, nr 1, s. $12-45$

Kudra, Andrzej, Dorota Jeziorska (2010), Językowe znaki świadomości kolektywnej i ich chiralna zasada konceptualizacyjna (o neonowomowie IVRP), [w:] Maciej Czerwiński, Paweł Nowak, Renata Przybylska (red.), Język IV Rzeczypospolitej, Wydawnictwo
Uniwersytetu Marii Curie-Skłodowskiej, Lublin

Lewis, Michael, Jeannette Haviland-Jones (2005), Psychologia emocji, Gdańskie Wydawnictwo Psychologiczne, Gdańsk

Lisiecka, Anna (2013), Reguty ekspresji emocjonalnej w relacji „my-oni”, [w:] Xymena Bukowska, Barbara Markowska (red.), To oni sq wszystkiemu winni. Język wrogości w polskim dyskursie publicznym, Wydawnictwo TRIO, Warszawa

Łaguna, Piotr (1984), Ironia jako postawa i jako wyraz, Wydawnictwo Literackie, Kraków-Wrocław

Markowska, Barbara (2013), Jacy „my” i jacy „oni”? Analiza semantyczna nazw i etykiet, [w:] Xymena Bukowska, Barbara Markowska (red.), To oni sq wszystkiemu winni. Język wrogości w polskim dyskursie publicznym, Wydawnictwo TRIO, Warszawa

Orwell, George (2010), Rok 1984, Warszawskie Wydawnictwo Literackie MUZA SA, Warszawa

Ożóg, Kazimierz (2004), Język w służbie polityki: językowy kształt kampanii wyborczych, Wydawnictwo Uniwersytetu Rzeszowskiego, Rzeszów

Przyłęcki, Paweł (2012), Populizm w polskiej polityce. Analiza dyskursu polityki, Wydawnictwo Sejmowe, Warszawa Retzinger, Suzanne, Thomas Scheff (2000), Emotion, alienation and narratives: Resolving Intractable Conflict, "Conflict Resolution Quarterly”, (18) 1, s. 71-85

Stomma, Ludwik (2000), Słownik polskich wyzwisk, inwektyw i określeń pejoratywnych, Oficyna Wydawnicza GRAFPUNKT, Warszawa 
Sztompka, Piotr (2005), Socjologia wizualna. Fotografia jako metoda badawcza, Wydawnictwo Naukowe PWN, Warszawa

Zimny, Rafał, Paweł Nowak (2009), Stownik polszczyzny politycznej po roku
1989, Wydawnictwo Naukowe PWN, Warszawa

Zybertowicz, Andrzej (2013), III RP. Kulisy systemu, Wydawnictwo Stowa i Myśli, Warszawa 